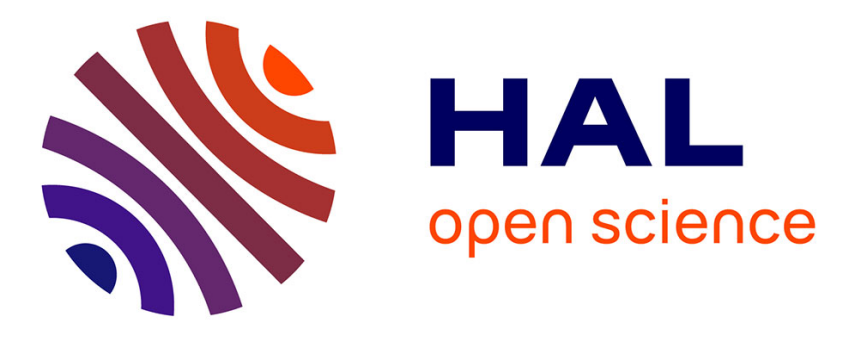

\title{
Hydrogeochemical processes in a small eastern mediterranean karst watershed (Nahr Ibrahim, Lebanon)
}

N Hanna, B. Lartiges, V. Kazpard, E Maatouk, N Amacha, S Sassine, A. El Samrani

\section{To cite this version:}

N Hanna, B. Lartiges, V. Kazpard, E Maatouk, N Amacha, et al.. Hydrogeochemical processes in a small eastern mediterranean karst watershed (Nahr Ibrahim, Lebanon). Aquatic Geochemistry, 2018, $10.1007 / \mathrm{s} 10498-018-9346-\mathrm{x}$. hal-02265626

\section{HAL Id: hal-02265626 \\ https://hal.science/hal-02265626}

Submitted on 10 Aug 2019

HAL is a multi-disciplinary open access archive for the deposit and dissemination of scientific research documents, whether they are published or not. The documents may come from teaching and research institutions in France or abroad, or from public or private research centers.
L'archive ouverte pluridisciplinaire HAL, est destinée au dépôt et à la diffusion de documents scientifiques de niveau recherche, publiés ou non, émanant des établissements d'enseignement et de recherche français ou étrangers, des laboratoires publics ou privés. 


\title{
Hydrogeochemical processes in a small eastern mediterranean karst watershed (Nahr Ibrahim, Lebanon)
}

\author{
N. Hanna ${ }^{1,2}$, B. Lartiges ${ }^{1 *}$, V. Kazpard², E. Maatouk ${ }^{2}$, \\ N. Amacha ${ }^{2}$, S. Sassine ${ }^{3}$, A. El Samrani ${ }^{2 *}$ \\ ${ }^{1}$ University of Toulouse (Paul Sabatier), Geosciences Environment Toulouse (UMR CNRS- \\ UPS 5563 IRD 234), 14 Av. E. Belin, 31400 Toulouse, France. \\ ${ }^{2}$ Lebanese University, Faculty of Sciences, EDST-PRASE, Laboratoire Geoscience, \\ Georessources \& Environment (L2GE), P.O Box. 26011217, Beirut-Lebanon. \\ ${ }^{3}$ Lebanese Scientific Research Council, Center of Remote Sensing, Mansourieh Lebanon
}

$\begin{array}{ll}\text { Corresponding authors: } & \text { A. EL SAMRANI (antoineelsamrani@ul.edu.lb) } \\ & \text { B. LARTIGES (bruno.lartiges@get.omp.eu) }\end{array}$

ORCID (B. LARTIGES): 0000-0003-1387-9942 


\begin{abstract}
Watersheds located in semi-arid areas such as the eastern Mediterranean are particularly sensitive to the impact of climate change. To gain knowledge on the hydrogeochemical processes occurring in the Nahr Ibrahim watershed, a Critical Zone Observatory in Lebanon, we analyze the isotopic composition of the river water as well as the concentrations of the major ions exported $\left(\mathrm{Ca}^{2+}, \mathrm{Mg}^{2+}, \mathrm{HCO}_{3}{ }^{-}, \mathrm{Na}^{+}, \mathrm{Cl}^{-}, \mathrm{K}^{+}, \mathrm{SO}_{4}{ }^{2-}\right)$. Sampling campaigns were conducted from March 2014 to August 2016 to capture contrasting hydrological conditions. The results indicate that the carbonate lithology of the watershed is the predominant source of $\mathrm{Ca}^{2+}, \mathrm{Mg}^{2+}$ and $\mathrm{HCO}_{3}{ }^{-}$, whereas the low contents of $\mathrm{Na}^{+}, \mathrm{Cl}^{-}, \mathrm{K}^{+}, \mathrm{SO}_{4}{ }^{2-}$ mainly originate from sea spray. Except in the headwaters, the Nahr Ibrahim River is oversaturated with respect to calcite and dolomite. During wet seasons, calcite and dolomite weathering contribute in an equivalent manner to the solute budget, whereas during dry seasons, calcite precipitates in the river. The isotopic composition of the river water reveals little seasonal dependency, the groundwater recharge by snowmelt infiltration leading to spring waters depleted in heavier isotopes during the dry seasons. A Carbonate Weathering rate of about $176 \mathrm{t} / \mathrm{km}^{2} / \mathrm{yr}$ was determined at the outlet of the Nahr Ibrahim watershed. The calculated values of $\mathrm{CO}_{2}$ partial pressure, on average twice the atmospheric pressure, suggest that the river is a significant source of $\mathrm{CO}_{2}$ to the atmosphere $(111 \mathrm{t} / \mathrm{yr})$.
\end{abstract}

Keywords: Karst watershed, Nahr Ibrahim River, carbonate weathering, water isotopes 


\section{Introduction}

The water fluxes in karst watersheds are the result of a complex interplay between surface water/groundwater interactions, climatic conditions, and human activities, mediated at longer time scales by tectonic and erosional processes (Cartwright et al. 2012; Diaw et al. 2012). The characteristic underground morphology of karsts (cracks, joints, fissures, conduits, and caves) leads to aquifers and streams highly responsive to environmental changes (Bakalowicz 2010; Bakalowicz et al. 2008; Calmels et al. 2014; Fayad et al. 2017; Ford and Williams 2007; Kaufmann 2009). Small Eastern Mediterranean karst watersheds, located in arid and semi-arid regions, are particularly sensitive to slight changes in rainfall pattern (Ammar et al. 2017; Bar-matthews and Ayalon 2004). Most often, such watersheds are prone to water scarcity because of uncontrolled over-exploitation of water resources and intensive groundwater withdrawal (Huang et al. 2013). In the context of a rapid climate change that will extend periods of drought, it has become urgent to better understand the dynamics of these Eastern Mediterranean karst watersheds, both in terms of water flow and water quality, in order to promote a sustainable water management of water resources (Bakalowicz 2010).

The objective of this study is to describe the hydrogeochemical functioning of a small karst catchment, the Nahr Ibrahim River watershed (Lebanon), using a combination of geochemical methods (major ions exported, calculation of solubility equilibria) and water isotopes tracers $\left(\delta^{18} \mathrm{O}\right.$ and $\left.\delta \mathrm{D}\right)$. The isotopic signature of water is a traditional tool in hydrology to provide information about the water origin and water fluxes (Clark and Fritz 1997; Gat 1996), whereas the seasonal trends and spatial patterns of major ions in the river describe the evolution of water quality. The Nahr Ibrahim watershed is, at the moment, a relatively pristine environment (proposed with its archeological remains on the Tentative List of UNESCO (Bou Saab et al. 2007)), and it was recently selected as a Critical Zone Observatory in the Mediterranean region (O-LIFE MISTRALS).

\section{Study Area}

\subsection{Geographical setting}

Situated in the west-central part of Lebanon, the Nahr Ibrahim River watershed extends from Mount Lebanon at an altitude of $2700 \mathrm{~m}$ to the Mediterranean littoral covering an area of 330 $\mathrm{km}^{2}$ (Figure 1). The Nahr Ibrahim River is a perennial second order stream of $30 \mathrm{~km}$ long 
that flows westward to discharge into the Mediterranean sea, $20 \mathrm{~km}$ north of Beirut (Darwich et al. 2015). Two permanent karstic springs, Afqa and Roueiss located at $1200 \mathrm{~m}$ and $1300 \mathrm{~m}$ of altitude, respectively, predominantly feed the Nahr Ibrahim River, although other temporary or permanent springs of lesser importance also flow to the main stream (Assaker 2016; Bou Saab et al. 2007; Korfali and Davies 2005). In the mountainous area, the Nahr Ibrahim River flows into a deeply incised valley that develops into narrow floodplains in the coastal lowlands before the estuary (El Samrani et al. 2005; Korfali and Davies 2004). The Nahr Ibrahim watershed is bounded to the East by the Yammouneh transform fault resulting from the movement of the Arabian plate. This complex geological structure leads to a system of steep-sided valleys oriented NE-SW, which episodically contribute to the main stream but remain dry 8 to 10 months per year.

\subsection{Climate and hydrology}

A typical Mediterranean climate prevails on the coastal area whereas the mountainous areas are cooler and more humid. The average annual precipitation on the Nahr Ibrahim watershed is $1200 \mathrm{~mm}$ (Khair et al. 1994). As shown in figure 2, most of the precipitation falls between November and April whereas no rainfall occurs in June, July and August (Amery 2002; Sene et al. 1999). During the period of the study, 2013-2014 was the driest year with only 45 days of rain and a total precipitation of $384 \mathrm{~mm}$. In contrast, 2014-2015 and 2015-2016 brought a similar number of rainy days (77 and 82, respectively), but differing amounts of total precipitation (906.8 and $519.2 \mathrm{~mm}$, respectively). Because of the high elevations of the watershed, the mountainous part is covered with snow during the wet season (Shaban et al. 2014). The maximum extent of snow cover varied from $387.99 \mathrm{~km}^{2}$ in $2013-2014,554.12$ $\mathrm{km}^{2}$ in 2014-2015, to reach $692.65 \mathrm{~km}^{2}$ in 2015-2016. As indicated in figure 2, snowmelt substantially contributes to the streamflow in the spring (Assaker 2016).

The annual average discharge of the Nahr Ibrahim River varies between $10.70 \mathrm{~m}^{3} / \mathrm{s}$ and 12.77 $\mathrm{m}^{3} / \mathrm{s}$ according to the source (Korfali and Davies 2005; Lebanese Ministry of Hydraulics and Electrical Resources 1999). The mean flow reaches $17.5 \mathrm{~m}^{3} / \mathrm{s}$ to $20.88 \mathrm{~m}^{3} / \mathrm{s}$ during the wet season whereas it decreases to $4-4.65 \mathrm{~m}^{3} / \mathrm{s}$ during the dry season. As a result, the stream flow can be either laminar or highly turbulent during the course of the year (Korfali and Davies 2000). During the low water period, the discharges at Afqa and at Roueiss springs are about $0.9 \mathrm{~m}^{3} / \mathrm{s}$, but only $0.5 \mathrm{~m}^{3} / \mathrm{s}$ reaches the stream because of pumping for irrigation (Nakhlé 2003). 


\subsection{Geology}

Various calcareous formations from the Middle Jurassic to the Upper Cretaceous form about $80 \%$ of the substrate of the Nahr Ibrahim watershed (Shaban et al. 2015) (Figure 1 and Table 1). However, sandstone, ferruginous, and basaltic outcrops, are also present in the watershed (Korfali and Davies 2005; Nakhlé 2003). The cretaceous formations outcrop near the coast and on the eastern part of the watershed heights where they are highly karstified. Fractured karstic limestones (C4-Cenomanian), massive dolostones (C3-Albian) and marls/dolomitic limestones (Lower and Middle Albian) are prevalent in these areas. Middle Jurassic formations occupy the central area of the watershed and are represented by weathered dolomites and bedded limestones (J6-Kimmeridgian) (Abdel-Rahman and Nader 2002). Both Cenomanian and Kimmeridgian formations are considered as excellent aquifers potentially connected with adjacent watersheds, i.e. Nahr El Jaouz to the North and Nahr El Kalb to the South (Shaban et al. 2015). Quaternary alluvial deposits are mainly found in the river outlet area whereas volcanic tuff outcrops upstream of the Nahr Ibrahim watershed.

\subsection{Land occupation use}

The population density of the Nahr Ibrahim watershed reaches 1700 inhabitant $/ \mathrm{km}^{2}$ (Daou et al. 2013). The urban areas, located near the coast, concentrate most of the industrial activity (Assaker 2016; Bou Saab et al. 2007; Korfali and Davies 2003). Thus, marble factories, food establishments, repair workshops, woodcrafts and various other factories (Plastic, paint, galvanizing, electroplating and ferrous industries) have been identified in the estuary region. The lack of sewerage networks and wastewater treatment facilities leads to discharges of domestic wastewater and industrial effluents into the river (Daou et al. 2013; El Samrani et al. 2005; Korfali and Davies 2004). The agricultural activities are spread throughout the watershed; they encompass many forms of land use including fruit trees cultivations as well as horticultures that can be accompanied by an excessive use of fertilizers (Daou et al. 2013; Korfali and Davies 2004).Three small hydroelectric plants using dams are also present in the Nahr Ibrahim watershed (Nakhlé 2003).

\section{Materials and methods}

\subsection{Data source and GIS mapping}

ArcGIS 12.2 was used to establish thematic maps of the Nahr Ibrahim watershed. The raw data (shapefiles for geology, hydrogeology, land cover, digital elevation models and drainage 
network) were provided by the National Council for Scientific Research - Lebanon (NCSRL), daily flow rates of Afqa and Roueiss springs and of Nahr Ibrahim River at the outlet were obtained from the Litani Authority, whereas daily measurements of ambient temperature, relative humidity and precipitations at the Akoura meteorological station (see Figure 1 for location), were provided by the Lebanese Agricultural Research Institute (LARI).

\subsection{Sampling and chemical analysis}

A total of 7 sites were sampled along the Nahr Ibrahim River, from the main springs to the estuary, between March 2014 and August 2016. The sites were selected to cover the spatial variability of land use and lithology (Figure 1 and Table 2). Sampling campaigns were performed during dry (June to October) and wet (November to May) seasons according to the discharge of the Nahr Ibrahim River. The $\mathrm{pH}$, temperature and electrical conductivity were measured on site using a portable LaMotte pocket multi Tracer-1766 calibrated according to the manufacturer's instructions. The accuracy of measurements was \pm 0.01 for $\mathrm{pH}, \pm 0.1^{\circ} \mathrm{C}$ for temperature and $\pm 2 \%$ for electrical conductivity. Samples collected for chemical and isotopic analyses were filtered over $0.45 \mu \mathrm{m}$ GRID MCE sterile membrane filters. The filtrates were stored in polyethylene bottles filled to the brim to avoid any evaporation and contact with the atmosphere. Samples for cation analysis were acidified with concentrated nitric acid to $\mathrm{pH}<2$. Samples for isotopic analysis were collected in separate plastic bottles of $50 \mathrm{ml}$. All the samples were then transported in a refrigerated box to the laboratory and stored at $4{ }^{\circ} \mathrm{C}$ awaiting analysis. Alkalinity was measured by acid titration within 24 hours of sampling. Anions $\left(\mathrm{SO}_{4}{ }^{2-}, \mathrm{Cl}^{-}, \mathrm{NO}_{3}{ }^{-}\right)$were analyzed by ion chromatography (Shimadzu LC$20 \mathrm{AD}$ - Shim-pack IC-A3 (S)) with a typical precision of $\pm 0.5 \%$, whereas major cations were analyzed by atomic absorption spectrophotometry $\left(\mathrm{Ca}^{2+}\right.$ and $\left.\mathrm{Mg}^{2+}\right)$ and flame photometry $\left(\mathrm{K}^{+}\right.$and $\left.\mathrm{Na}^{+}\right)$using a Sherwood Flame Photometer (Model 420) with a precision of $\pm 1 \%$ and a repeatability of $0.3 \%$. To check the consistency of the results, charge balance (CB) calculations were performed using the relationships: $\mathrm{CB}=100 \times\left(\sum \mathrm{C}_{\text {cations }}-\sum\right.$

$\left.\mathrm{C}_{\text {anions }}\right) /\left(\sum \mathrm{C}_{\text {cations }}+\sum \mathrm{C}_{\text {anions }}\right)$, where $\mathrm{C}$ represents the concentration in meq $\mathrm{L}^{-1}$. As shown in the supporting information section, about $90 \%$ of CB was below $5 \%$.

The isotopic signature of water samples was obtained using a Liquid Water Isotope Analyzer (LWIA-24d). Each sample was measured six times according to a standard calibration curve using VSMOW (Vienna Standard Mean Ocean Water) certified standards following IAEA norms (International Atomic Energy Agency 2009). The $\delta^{18} \mathrm{O}$ and $\delta \mathrm{D}$ are reported using the 
delta notation in per mill (\%) relative to VSMOW water stable isotopes with a precision of better than $0.1 \%$ for $\delta^{18} \mathrm{O}$ and $0.3 \%$ for $\delta \mathrm{D}$.

\section{Results}

\subsection{Water chemistry}

The physico-chemical characteristics of water samples collected during both wet and dry seasons between 2014 and 2016 are listed in Table 3. The $\mathrm{pH}$ values, ranging from 7.57 to 8.8, are in line with those previously reported for the Nahr Ibrahim watershed by Khalaf (1984), El Samrani et al. (2005) and Assaker (2016). As illustrated in figure 3, the pH is about 0.3 units higher during wet periods compared with dry periods, whereas the $\mathrm{pH}$ of Afqa and Roueiss springs is slightly lower than those of river water samples. The electrical conductivity of water ranges from 196 to $410 \mu \mathrm{S} / \mathrm{cm}$ with an average value of $261 \pm 53$ $\mu \mathrm{S} / \mathrm{cm}$. Springs show lower conductivities than water samples taken downstream and EC are higher during the dry season.

The Piper diagram for the Nahr Ibrahim water samples is shown in figure 4. As expected for waters draining essentially limestones and dolomites (Saad et al. 2005a; Williams et al. 2007), $\mathrm{Ca}^{2+}-\mathrm{Mg}^{2+}-\mathrm{HCO}_{3}{ }^{-}$type waters prevail with the abundance of major cations and anions in the order $\mathrm{Ca}^{2+}>\mathrm{Mg}^{2+}>\mathrm{Na}^{+}>\mathrm{K}^{+}$and $\mathrm{HCO}_{3}>\mathrm{Cl}^{-}>\mathrm{SO}_{4}{ }^{2-}$, respectively. Thus, all the samples are clustered at the $\mathrm{HCO}_{3}{ }^{-}+\mathrm{CO}_{3}{ }^{2-}$ pole of the anion triangle, whereas $\mathrm{Ca}^{2+}$ and $\mathrm{Mg}^{2+}$ clearly dominate the cation triangle with relative percentages exceeding $70 \%$ and $25 \%$, respectively. $\mathrm{A} \mathrm{Ca}^{2+}$ to $\mathrm{Mg}^{2+}$ trend is observed along the Nahr Ibrahim course, both spring waters (Afqa and Roueiss) being characterized by a lower $\mathrm{Mg}^{2+}$ content and a higher $\mathrm{Ca}^{2+}$ content compared with the other surface waters. $\mathrm{Cl}^{-}$and $\mathrm{SO}_{4}{ }^{2-}$ represent only minor contributions to the cation-anion balance, which is consistent with the lithology of the Nahr Ibrahim watershed. Water samples collected in 2014, the driest year of the study, reveal a slight enrichment in $\mathrm{Na}^{+}$and $\mathrm{Cl}^{-}$downstream of the watershed. In addition, a seasonal comparison indicates that the samples taken during the dry season are $\mathrm{Mg}^{2+}$-enriched and $\mathrm{Ca}^{2+}$-depleted.

\subsection{Water stable isotopes}

The isotopic signature of Nahr Ibrahim waters is consistent with the regional context. As shown in figure 5 , all the $\delta \mathrm{D}-\delta^{18} \mathrm{O}$ values align with the Lebanese Meteoric Water Line $(\delta \mathrm{D}=$ 
$\left.7.135 * \delta^{18} \mathrm{O}+15.979\right)$ established by Saad et al. (2005b). No clear seasonal trend can be evidenced, the difference between average $\delta^{18} \mathrm{O}$ measured during wet and dry season being at most $0.6 \%$ for a given sampling site. Therefore, waters sampled during the dry season do not reveal a significant evaporation process that would preferentially enrich the water in heavy stable isotopes. Stated in other terms, during the dry season, the Nahr Ibrahim River is essentially fed by local karstic aquifers and not by irrigation return flows. Spring waters taken at an altitude of about $1600 \mathrm{~m}$ are more depleted in heavy isotopes than waters sampled downstream close to the coast. The corresponding decrease of isotopic ratios can be explained by an altitude effect on the isotopic composition of local precipitations (Mook 2001). Saad et al. (2005a) found a decrease of the order of $-0.3 \% / 100 \mathrm{~m}$ for $\delta^{18} \mathrm{O}$ in precipitations in the same geographical area.

\subsection{Major ions geochemistry}

To identify the main lithological sources of solutes in the Nahr Ibrahim River, plots of $\left[\mathrm{Ca}^{2+}\right]$ $+\left[\mathrm{Mg}^{2+}\right]$ against $\left[\mathrm{HCO}_{3}{ }^{-}\right]$, and $\left[\mathrm{Mg}^{2+}\right]$ against $\left[\mathrm{Ca}^{2+}\right]$, were drawn. As shown in figure 6 a, the majority of water samples exhibit a $2: 1$ mole ratio of $\mathrm{HCO}_{3}{ }^{-}$to $\mathrm{Ca}^{2+}+\mathrm{Mg}^{2+}$ in accordance with the dissolution reactions of calcite and dolomite:

$$
\begin{aligned}
& \text { Calcite: } \mathrm{CaCO}_{3}+\mathrm{CO}_{2}+\mathrm{H}_{2} \mathrm{O} \leftrightarrow \mathrm{Ca}^{2+}+2 \mathrm{HCO}_{3}{ }^{-} \\
& \text {Dolomite: } \mathrm{Ca}_{\mathrm{x}} \mathrm{Mg}_{(1-\mathrm{x})} \mathrm{CO}_{3}+\mathrm{CO}_{2}+\mathrm{H}_{2} \mathrm{O} \leftrightarrow \mathrm{xCa}^{2+}+(1-\mathrm{x}) \mathrm{Mg}^{2+}+2 \mathrm{HCO}_{3}{ }^{-}
\end{aligned}
$$

The slight excess in $\left[\mathrm{HCO}_{3}{ }^{-}\right]$observed during wet seasons (data points below the theoretical 1:2 dissolution line) may be attributed to the presence in the water of small amounts of dissolved organic matter that contribute to alkalinity.

The $\mathrm{Mg}^{2+} / \mathrm{Ca}^{2+}$ molar ratios, shown in figure $6 \mathrm{~b}$, are generally used to provide an insight into the relative contributions of dolomite and/or calcite dissolution to the dissolved load. Thus, the dissolution of dolomite alone leads to $\mathrm{Mg}^{2+} / \mathrm{Ca}^{2+}$ ratios equal to 1 , that of calcite containing traces of $\mathrm{Mg}^{2+}$ is characterized by $\mathrm{Mg}^{2+} / \mathrm{Ca}^{2+}$ ratios less than 0.1 , whereas the congruent dissolution of calcite and dolomite leads to $\mathrm{Mg}^{2+} / \mathrm{Ca}^{2+}$ ratios of about 0.33 (Szramek et al. 2011; Williams et al. 2007). The water samples from the Nahr Ibrahim River generally cluster between the 0.1 and 0.5 theoretical lines (average of 0.36 ), except for waters collected during dry seasons where $\mathrm{Mg}^{2+} / \mathrm{Ca}^{2+}$ ratios as high as 0.86 can be obtained. Therefore, on average, the dissolutions of calcite and dolomite contribute in an equivalent 
manner to the dissolved load of the Nahr Ibrahim River. The $\mathrm{Mg}^{2+}$ enriched waters collected during dry seasons likely result from a preferential precipitation of calcite (Drever 1997; Langmuir 1997; Szramek and Walter 2004). Indeed, during the dry period, if the river water becomes oversaturated both for calcite and dolomite, calcite precipitation is favored over dolomite for kinetic reasons (Jin et al. 2010). As a result, the preferential loss of $\mathrm{Ca}^{2+}$ increases the $\mathrm{Mg}^{2+} / \mathrm{Ca}^{2+}$ ratio of the water.

Concentrations of $\mathrm{Na}^{+}, \mathrm{K}^{+}$, and $\mathrm{SO}_{4}{ }^{2-}$ as a function of $\mathrm{Cl}^{-}$concentration are shown in figure 7 . A significant correlation is observed with the level of $\mathrm{Cl}^{-}$in the lower range of $\mathrm{Na}^{+}, \mathrm{K}^{+}$, and $\mathrm{SO}_{4}{ }^{2-}$ concentrations, the molar ratios $\mathrm{Na}^{+} / \mathrm{Cl}^{-}, \mathrm{SO}_{4}{ }^{2-} / \mathrm{Cl}^{-}$, and $\mathrm{K}^{+} / \mathrm{Cl}^{-}$then being equal to 0.91 , $0.66,0.07$, respectively. As no evaporite lithology has been noted in the watershed, those values, close to those found in sea salt aerosols, are consistent with a substantial contribution of sea spray (both in the form of wet and dry depositions) to the solute budget of the Nahr Ibrahim River (Al-Momani et al. 1995; Im 2013; Whipkey et al. 2000; Zhu et al. 2012). Nevertheless, an additional contribution in $\mathrm{SO}_{4}{ }^{2-}$ and $\mathrm{K}^{+}$detected close to the outlet during the dry season, probably corresponds to a contribution of the local aquifer or even a slight input in fertilizers from irrigation flows (Azzi et al. 2017).

\subsection{Downstream evolution of water chemistry}

Despite drastic differences in the seasonal pattern of weathering, the Nahr Ibrahim River displays a typical downstream evolution during both wet and dry periods. Spring waters at Afqa and Roueiss show systematically lower concentrations in $\mathrm{Ca}^{2+}, \mathrm{Mg}^{2+}$ and $\mathrm{HCO}_{3}^{-}$than those of stream water (Figure 8). Then, the levels in $\mathrm{Ca}^{2+}$ and $\mathrm{HCO}_{3}{ }^{-}$remain fairly constant on average up to the outlet, whereas the concentration of $\mathrm{Mg}^{2+}$ significantly increases especially during the dry season. The latter observation can be related to the watershed lithology: if limestone (Albian-Cenomanian) dominates the geology at the head of the watershed, dolostone interbedded with limestone (Kimmeridgian) occurs predominantly in the central area of the watershed (Figure 1). An estimate of $54.7 \%$ dolomite weathering has thus been calculated for the Jurassic aquifer (Nader et al., 2008). In addition, the water draining the alluvial deposits of Quaternary age is expected to contribute to the $\mathrm{Mg}^{2+}$ content of the surface water (Zavadlav et al. 2013; Kanduc et al. 2013). Nevertheless, it should be noted that, during the dry season, both $\mathrm{Ca}^{2+}$ and $\mathrm{HCO}_{3}{ }^{-}$concentrations significantly drop at the Yahshoush sampling site, which is attributed to a preferential calcite precipitation (Nader et al. 2008; Singurindy and Berkowitz 2003). 
As illustrated in figure 8, the downstream evolution of $\mathrm{Na}^{+}, \mathrm{K}^{+}, \mathrm{Cl}^{-}$and $\mathrm{SO}_{4}{ }^{2-}$ is consistent with a dominant sea-spray contribution to the solute budget of the Nahr Ibrahim River for those elements. Close to the coast (Outlet, Yashoush, Janneh) and during the wet season, the average levels of $\mathrm{Na}^{+}, \mathrm{K}^{+}$, and $\mathrm{SO}_{4}{ }^{2-}(0.155 \pm 0.032,0.011 \pm 0.002$, and $0.103 \pm 0.22 \mathrm{mmol} / \mathrm{L}$, respectively) are comparable with those found in wet precipitations in the eastern mediterannean region (Al-Momani et al. 1995; Saad et al. 2005b). In contrast, the lower concentrations measured at upstream sampling sites are consistent with a fractionation effect that occurs during the formation of precipitations and is enhanced both by the distance to the marine source and the increase in altitude (Meier et al. 2015; Stallard and Edmond 1981; Whipkey et al. 2000; Zhu et al. 2012). Such combined effects are particularly obvious from the linear correlation observed when plotting the $\mathrm{Cl}^{-}$concentration against $\delta \mathrm{D}$ (Figure 9): indeed, the sites close to the coast are slightly depleted in heavy isotopes and present the highest $\mathrm{Cl}^{-}$concentration, whereas the high altitude sites show the lowest $\delta \mathrm{D}$ and the lowest $\mathrm{Cl}^{-}$concentration.

The patterns of $\mathrm{K}^{+}$and $\mathrm{SO}_{4}{ }^{2-}$ concentrations exhibit a pronounced maximum at the Janneh sampling site during the dry season. Basaltic outcrops $(\beta \mathrm{J} 6$ and $\beta C 2)$ are present in this area of the watershed (Figure 1), and some silicates (feldspars, pyroxenes...) might release $\mathrm{K}^{+}$ through weathering (Roy et al. 1999). However, the close correlation between $\mathrm{K}^{+}$and $\mathrm{SO}_{4}{ }^{2-}$ concentrations (Figure 7d), suggests a common origin for the two ions. The $\mathrm{C} 4$ cretaceous formation that occurs around Janneh as anoxic marls containing some pyrite, might contribute to the release of both $\mathrm{K}^{+}$and $\mathrm{SO}_{4}{ }^{2-}$. The leaching of fertilizers used in agriculture could also account for the presence of those two ions (Azzi et al. 2017).

\section{Discussion}

\subsection{Groundwater contribution to surface water outflow}

As many karstic areas around the Mediterranean, the Nahr Ibrahim watershed has undergone drastic base-level changes during Miocene to Quaternary times. In particular, the Messinian Salinity Crisis (5.96-5.33 Ma), associated with a drastic sea-level drop of more than 1000 m (Krijgsman et al. 1999), led to the deep incision of the Nahr Ibrahim canyon. The opening of the Gibraltar strait at the beginning of Pliocene flooded the karstified limestones and partially filled the cavities with marine sediments. During Quaternary, the 
successive glacial and interglacial periods with concomitant changes in sea level, periods of enhanced erosion followed by continental sediment accumulation, formed an important part of the history of this complex multi-phase karstic system whose detailed description is beyond the scope of this paper.

Afqa and Roueiss, the two main permanent springs that feed the Nahr Ibrahim River, are both located at the base of the highly karstified Cenomanian-Turonian carbonate formation. The two spring waters present close physico-chemical characteristics (temperature, $\mathrm{pH}$, conductivity) as well as similar solute contents and isotopic signatures. Previous study of the hydrogeological functioning of Afqa aquifer (Bakalowicz et al. 2008) has indicated that the groundwater recharge is essentially controlled by snow melt and that the mean residence time of water in the phreatic zone is about 2.5 months. Indeed, as can be followed in figure 2, any significant decrease in snow cover area leads to a flood peak on the hydrograph with a time delay of about one month. Such observation is in line with the significant enrichment in heavy isotopes observed for spring waters during the dry season (Fig. 5). The water isotope composition of the downstream sampling sites is similar for a given site regardless of the season. On the one hand, the upstream water withdrawals attenuate the impact of permanent springs on the isotopic signature of downstream sites that then reflect the influence of local aquifers. On the other hand, those sites are situated at a lower altitude and in a warmer environment where snowfall is much less frequent. As a result, the water isotope signature of sampling sites essentially reflects the altitude effect on the isotopic content of the local rainfall.

\subsection{Dolomite and Calcite contribution to the total carbonate weathering}

The Nahr Ibrahim hydrogeochemistry is dominated by the weathering of carbonate minerals by carbonic acid. The high $\mathrm{Mg}^{2+} / \mathrm{Ca}^{2+}$ ratios observed during the dry season, suggest a calcite precipitation process. Saturation indexes were calculated using Visual Minteq (version 2.3) according to the following equations: $\mathrm{SI}_{\text {calcite }}=\log \left(\mathrm{IAP}_{\text {calcite }} / \mathrm{K}_{\text {calcite }}\right)$ and $\mathrm{SI}_{\text {dolomite }}=\log \left(\mathrm{IAP}_{\text {dolomite }} / \mathrm{K}_{\text {dolomite }}\right)$ where calcite and dolomite ion activity products are respectively $\mathrm{IAP}_{\text {calcite }}=\left[\mathrm{Ca}^{2+}\right] \cdot\left[\mathrm{CO}_{3}{ }^{2-}\right]$ and $\mathrm{IAP}_{\text {dolomite }}=\left[\mathrm{Ca}^{2+}\right] \cdot\left[\mathrm{Mg}^{2+}\right] \cdot\left[\mathrm{CO}_{3}{ }^{2-}\right]$ and $\mathrm{K}_{\text {calcite }}$ and $\mathrm{K}_{\text {dolomite }}$ their respective solubility products (Langmuir 1997). As illustrated in Figure 10, calcite and dolomite saturation indexes $\left(\mathrm{SI}_{\mathrm{dol}}\right.$ and $\left.\mathrm{SI}_{\mathrm{cal}}\right)$ are frequently well above equilibrium $\left(\mathrm{SI}_{\text {equilibrium }}=0\right)$ especially for downstream river waters. Nevertheless, during the dry season, the river water is less saturated with respect to calcite, and Afqa and Roueiss springs are even 
close to equilibrium. The calculated values of $\mathrm{CO}_{2}$ partial pressure vary from $355 \mathrm{ppm}$ to $3392 \mathrm{ppm}$, i.e. from near equilibrium with atmospheric pressure to about 8-fold supersaturated river water during dry season at the outlet (See Figure S1 in Supporting Information). On average, the $\mathrm{pCO} 2$ concentration is about twice the atmospheric value.

The Carbonate Weathering Rate (CWR) can be calculated at the outlet of the watershed using the equation: $\mathrm{CWR}=\left(\mathrm{Ca}+\mathrm{Mg}+0.5 \times \mathrm{HCO}_{3}\right) \times \mathrm{Q} \div \mathrm{A}$ where $\mathrm{Q}$ is the discharge at the outlet $(1 / \mathrm{yr}), \mathrm{A}$ the drainage area $\left(\mathrm{km}^{2}\right), \mathrm{Ca}^{2+}, \mathrm{Mg}^{2+}, \mathrm{HCO}_{3}{ }^{2+}$ the respective concentrations of the elements (mg/l), and CWR in $\mathrm{t} / \mathrm{km}^{2} / \mathrm{yr}$ (Zavadlav et al. 2013). An average CWR of $176.29 \mathrm{t} / \mathrm{km}^{2} / \mathrm{yr}$ is thus obtained for the entire period of study. Because of the higher flow rate of the river, the CWR is higher and equal to $231.8 \mathrm{t} / \mathrm{km}^{2} / \mathrm{yr}$ during the wet season. Values equal to $499.3 \mathrm{t} / \mathrm{km}^{2} / \mathrm{yr}$ can even be reached during the period of snowmelt. Nevertheless, such values remain consistent with those reported in the literature for karstic watersheds, i.e. $133 \mathrm{t} / \mathrm{km}^{2} / \mathrm{yr}$ (Li et al., 2010), $394.9 \mathrm{t} / \mathrm{km}^{2} / \mathrm{yr}$ (Sun et al. 2010), or $121 \mathrm{t} / \mathrm{km}^{2} / \mathrm{yr}$ (Zavadlav et al. 2013). In particular, a recent study by Assaker (2016) gave a CWR of $219 \mathrm{t} / \mathrm{km}^{2} / \mathrm{yr}$ for the Nahr Ibrahim watershed, which is in accordance with our findings.

Following the method described in Kanduc et al. (2012; 2013), the flux of $\mathrm{CO}_{2}$ degassed by the river can be calculated using $\mathrm{F}_{\mathrm{CO} 2}=\mathrm{K}\left(\left[\mathrm{CO}_{2}\right]_{\mathrm{eq}}-\left[\mathrm{CO}_{2}\right]\right)$, where $\mathrm{K}$ is the liquid film transfer for $\mathrm{CO}_{2}$, and $\left[\mathrm{CO}_{2}\right]_{\mathrm{eq}}$ and $\left[\mathrm{CO}_{2}\right]$ are the concentrations of dissolved $\mathrm{CO}_{2}$ in equilibrium with the atmosphere and of calculated $\mathrm{CO}_{2}$ in the water proximate to the interface, respectively. $\mathrm{K}$ depends on the mean wind speed above the water and the flowing conditions in the river channel. The detailed wind pattern over the Nahr Ibrahim River is not known at the moment, nor are the flowing conditions that vary significantly between the springs and the outlet. At first approximation, using a value of $\mathrm{K}$ equal to $28 \mathrm{~cm} / \mathrm{h}$ (moderate turbulence conditions under a mean wind speed of $4 \mathrm{~m} / \mathrm{s}), \mathrm{F}_{\mathrm{CO} 2}$ is about $4.810^{-7} \mathrm{~mol} / \mathrm{cm}^{2} \mathrm{~h}$. Taking an approximate mean width of $2 \mathrm{~m}$ for the $30 \mathrm{~km}$-long Nahr Ibrahim River, the average annual amount of $\mathrm{CO}_{2}$ emitted by the river to the atmosphere is $0.2510^{7} \mathrm{~mol} / \mathrm{yr}$ or $111 \mathrm{t} / \mathrm{yr}$, which is equivalent to the flux of dissolved inorganic carbon at the outlet.

\section{Conclusion}

The water chemical composition and the isotopic signature of water $\left(\delta^{18} \mathrm{O}\right.$ and $\left.\delta \mathrm{D}\right)$ were used to describe the hydrogeochemical functioning of the Nahr Ibrahim River situated in a small karstic watershed in Lebanon. The dominant ions of the solute load are $\mathrm{Ca}^{2+}, \mathrm{Mg}^{2+}$ and 
$\mathrm{HCO}_{3}{ }^{-}$. Concentrations of $\mathrm{HCO}_{3}{ }^{-}$vary seasonally from $2.6 \mathrm{mM}$ to $4 \mathrm{mM}$ according to the discharge. $\mathrm{Ca}^{2+}, \mathrm{Mg}^{2+}$ and $\mathrm{HCO}_{3}{ }^{-}$are found in a 2:1 mole ratio of $\mathrm{HCO}_{3}{ }^{-}$to $\mathrm{Ca}^{2+}+\mathrm{Mg}^{2+}$, thus indicating that carbonate weathering by carbonic acid is the main source of solutes in the watershed. An additional contribution from sea spray accounts for the contents in $\mathrm{Na}^{+}$and $\mathrm{Cl}^{-}$ in the river. Except in the headwaters, the river water is found oversaturated with respect to calcite and dolomite. The seasonal variations of $\mathrm{Mg}^{2+} / \mathrm{Ca}^{2+}$ ratio reveal that the dissolution of calcite and dolomite contributes in an equivalent manner to the dissolved load of the Nahr Ibrahim River during the wet season. In contrast, $\mathrm{Mg}^{2+}$-enriched waters collected during the dry season identify a calcite precipitation process in the river. A Carbonate Weathering rate of about $176 \mathrm{t} / \mathrm{km}^{2} / \mathrm{yr}$ was determined at the outlet of the Nahr Ibrahim watershed. The calculated values of $\mathrm{CO}_{2}$ partial pressure, on average twice the atmospheric pressure, suggest that the river is a significant source of $\mathrm{CO}_{2}$ to the atmosphere $(111 \mathrm{t} / \mathrm{yr})$.

The isotopic signature of water of the spring water reflects the snowmelt recharge of the aquifer, especially during the dry season. The spatial variation of the isotopic composition of the river water results from an altitude effect on the precipitation composition, and indicates that the Nahr Ibrahim River is a groundwater-dominated river even during the wet season. This initial assessment of the water chemistry of the Nahr Ibrahim River provides a baseline measure against which we can assess the environmental impacts of water withdrawals in the watershed and we can monitor the evolution of water chemistry in the context of climate change.

Acknowledgments: This project was supported by grants from the Lebanese University and the Lebanese Council for Scientific Research. Nour Hanna and Antoine El Samrani also gratefully acknowledge the support of Azm and Saadé Association. The authors would like to thank the Remote Sensing Center of the Lebanese National Council for Scientific Research (NCSR-L) and the Lebanese Agricultural Research Institute (LARI) for providing us with the needed data and measurements relative to the Nahr Ibrahim watershed during the period of study. The authors would also like to thank Mr. Hussein Kanbar, Mrs Yara Rahmé and Mr Hamze Mohieddine for their assistance during the sampling campaigns. Insightful suggestions on the manuscript from Dr. C. Destrigneville were also appreciated. 


\section{References}

Abdel-Rahman AFM, Nader FH (2002) Characterization of the Lebanese Jurassic-Cretaceous carbonate stratigraphic sequence: A geochemical approach. Geol J 37:69-91. doi:10.1002/gj.902

Al-Momani IF, Ataman OY, Anwari MA, Tuncel S, Kose C, Tuncel G (1995) Chemical composition of precipitation near an industrial area at Izmir, Turkey. Atmos Environ 29:1131-1143. doi:10.1016/1352-2310(95)00027-V

Amery HA (2002) Irrigation Planning in Lebanon: Challenges and Opportunities, in: Mehmet, Ö., Biçak, H.A. (Eds.), Modern and Traditional Irrigation Technologies in the Eastern Mediterranean, IDRC 2002 publication, Ottawa, Ontario Canada, p. 212.

Ammar R, Kazpard V, El Samrani AG, Amacha N, Saad Z, Chou L (2017) Hydrodynamic influence on reservoir sustainability in semi-arid climate: A physicochemical and environmental isotopic study. J Environ Manage 197:571-581. doi:10.1016/j.jenvman.2017.04.030

Assaker A (2016) Hydrologie et Biogéochimie du Bassin Versant du Fleuve Ibrahim: Un Observatoire du Fonctionnement de la Zone Critique au Liban. Ph.D. Thesis, Institut National Polytechnique de Toulouse (INP Toulouse), France.

Azzi V, Kazpard V, Lartiges B, Kobeissi A, Kanso A, El Samrani AG (2017). Trace Metals in Phosphate Fertilizers Used in Eastern Mediterranean Countries. Clean - Soil, Air, Water 45. doi:10.1002/clen.201500988

Bakalowicz M (2010) Karst et ressources en eau souterraine : un atout pour le développement des pays méditerranéens. Sécheresse 21:1-6. doi:10.1684/sec.2010.0275

Bakalowicz M, El Hakim M, El-Hajj A (2008). Karst groundwater resources in the countries of eastern Mediterranean: The example of Lebanon. Environ Geol 54:597-604. doi:10.1007/s00254-007-0854-z

Bar-matthews M, Ayalon A (2004) Speleothems as palaeoclimate indicators, a case study from Soreq Cave located in the Eastern Mediterranean Region, Israel, in: Battarbee, R.W., Gasse, F., Stickley, C.E. (Eds.), Past Climate Variability through Europe and 
Africa. Kluwer Academic Publishers, Dordrecht, The Netherlands, pp. 363-391. doi:10.1007/978-1-4020-2121-3

Bou Saab H, Nassif N, El Samrani AG, Daoud R, Medawar S, Ouaïni N (2007) Suivi de la qualité bactériologique des eaux de surface (rivière Nahr Ibrahim, Liban). Rev Sci Eau 20: 341. doi:10.7202/016909ar

Calmels D, Gaillardet J, François L (2014) Sensitivity of carbonate weathering to soil CO2 production by biological activity along a temperate climate transect. Chem Geol 390:74-86. doi:10.1016/j.chemgeo.2014.10.010

Cartwright I, Weaver TR, Cendón DI, Fifield LK, Tweed SO, Petrides B, Swane I (2012) Constraining groundwater flow, residence times, inter-aquifer mixing, and aquifer properties using environmental isotopes in the southeast Murray Basin, Australia. Appl Geochemistry 27:1698-1709. doi:10.1016/j.apgeochem.2012.02.006

Clark I, Fritz P (1997) Environmental Isotopes in Hydrogeology. Lewis Publishers, New York.

Daou C, Salloum M, Mouneimne AH, Legube B, Ouaini N (2013) Multidimensionnal Analysis Of Two Lebanese Surface Water Quality: Ibrahim And El-Kalb Rivers. J. Appl Sci Res 9:2777-2787.

Darwich T, Assaker A, Faour G, Noun M, Poupet P, Harfouche R (2015) Utilisation de la Télédétection et des Techniques SIG pour l'Évaluation et la Cartographie des Risques de Feux de Forêts dans le Bassin Versant du Nahr Ibrahim, in: Harfouche, R., Poupet, P. (Eds.), Du Mont Liban Aux Sierras d'Espagne. Sols, Eau et Sociétés En Montagne. Archaeopress Publishing Ltd., Oxford, England, pp. 137-146.

Diaw M, Faye S, Stichler W, Maloszewski P (2012) Isotopic and geochemical characteristics of groundwater in the Senegal River delta aquifer: Implication of recharge and flow regime. Environ Earth Sci 66:1011-1020. doi:10.1007/s12665-010-0710-4

Drever JI (1997) The geochemistry of natural waters: surface and groundwater environments. Prentice Hall.

El Samrani AG, Kazpard V, Ouaïni N, Lartiges BS, Slim K, Saad Z (2005) Trace element 
carriers in river sediments ( Ibrahim River-Lebanon ): Investigation on natural and anthropogenic inputs. Int J Civ Environ Eng 1:1-16.

Fayad A, Gascoin S, Faour G, Lopez-Moreno JI Drapeau, L Page, M Le, Escadafal R (2017) Snow hydrology in Mediterranean mountain regions: a review. J Hydrol 551:374-396. doi:10.1016/j.jhydrol.2017.05.063

Ford D, Williams P (2007) Karst Hydrology and Geomorphology, Karst Hydrogeology and Geomorphology. John Wiley \& Sons Ltd., West Sussex, England. doi:10.1002/9781118684986

Gat JR (1996) Oxygen and hydrogen isotopes in the hydrologic cycle. Annu Rev Earth Planet Sci 24:225-262.

Huang G, Sun J, Zhang Y, Chen Z, Liu F (2013) Impact of anthropogenic and natural processes on the evolution of groundwater chemistry in a rapidly urbanized coastal area, South China. Sci Total Environ 463-464:209-221. doi:10.1016/j.scitotenv.2013.05.078

Im U (2013) Impact of sea-salt emissions on the model performance and aerosol chemical composition and deposition in the East Mediterranean coastal regions. Atmos Environ 75:329-340. doi:10.1016/j.atmosenv.2013.04.034

International Atomic Energy Agency (2009) VSMOW2 and SLAP2 Reference Sheet, Reference Sheet for International Measurement Standards.

Jin L, Siegel DI, Lautz LK, Mitchell MJ, Dahms DE, Mayer B (2010) Calcite precipitation driven by the common ion effect during groundwater-surface-water mixing: A potentially common process in streams with geologic settings containing gypsum. Bull Geol Soc Am 122:1027-1038. doi:10.1130/B30011.1

Kanduc T, Sturm M, Zigon S, McIntosh J (2012) Tracing biogeochemical processes and pollution sources with stable isotopes in river systems: Kamniska Bistrica, North Slovenia. Biogeosciences Discuss. 9, 9711-9757. doi: 10.5194/bgd-9-9711-2012

Kanduc T, Burnik Sturm M, McIntosh J (2013) Chemical dynamics and evaluation of biogeochemical processes in alpine river Kamniska Bistrica, North Slovenia. Aquat Geochem19:323-346. doi 10.1007/s10498-013-9197-4 
Kaufmann G (2009) Modelling karst geomorphology on different time scales. Geomorphology 106:62-77. doi:10.1016/j.geomorph.2008.09.016

Khair K, Aker N, Haddad F, Jurdi M, Hachach A (1994) The environmental impacts of humans on groundwater in Lebanon. Water Air Soil Pollut 78:37-49. doi:10.1007/BF00475666

Khalaf G. (1984) Contribution à l'étude écologique des fleuves côtiers du Liban : 2 . Cours moyen et inférieur du Nahr Ibrahim. Bull. Mens. la Société linnéenne Lyon 53:9-20.

Korfali SI, Davies BE (2005) Seasonal variations of racte metal chemical forms in bed sediments of a karstic river in Lebanon: Implications for self-purification. Environ Geochem Health 27:385-395. doi:10.1007/s10653-004-7096-8

Korfali SI, Davies BE (2004) The relationships of metals in river sediments (Nahr-Ibrahim, Lebanon) and adjacent floodplain soils. Agric Eng Int CIGR J Sci Res Dev 6:1-22. doi:10.1007/s13398-014-0173-7.2

Korfali SI, Davies BE (2003) A comparison of metals in sediments and water in the river Nahr-Ibrahim, Lebanon: 1996 and 1999. Environ Geochem Health 25:41-50. doi:10.1023/A:1021284126632

Korfali SI, Davies BE (2000) Total and Extractable Trace Elements in Lebanese River Sediments : Dry Season Data. Environ Geochem Health 22:265-273.

Krijgsman W, Hilgen FJ, Raffi I, Sierro FJ, Wilson DS (1999) Chronology, causes and progression of the Messinian Salinity Crisis. Nature 400:652-655.

Langmuir D (1997) Aqueous Environmental Geochemistry. Prentice-Hall, Inc., Upper Saddle River, New Jersey 07458.

Lebanese Ministry of Hydraulics and Electrical Resources (1999) Annual average discharge of the Nahr Ibrahim River.

Li SL, Liu CQ, Li J, Lang YC, Ding H, Li L (2010) Geochemistry of dissolved inorganic carbon and carbonate weathering in a small typical karstic catchment of Southwest China: Isotopic and chemical constraints. Chem Geol 277:301-309. doi:10.1016/j.chemgeo.2010.08.013 
Meier SD, Atekwana EA, Molwalefhe L, Atekwana EA (2015) Processes that control water chemistry and stable isotopic composition during the refilling of Lake Ngami in semiarid northwest Botswana. J Hydrol 527:420-432. doi:10.1016/j.jhydrol.2015.04.050

Mook WG (2001) Environmental Isotopes in the Hydrological Cycle - Principles and Applications, IAEA UNESCO. Paris / Vienna.

Nader FH, Swennen R, Keppens E (2008) Calcitization/dedolomitization of Jurassic dolostones (Lebanon): results from petrographic and sequential geochemical analyses. Sedimentology 55:1467-1485. doi:10.1111/j.1365-3091.2008.00953.x

Nakhlé KF (2003) Le Mercure, le Cadmium et le Plomb dans les Eaux Littorales Libanaises: Apports et Suivi au Moyen de Bioindicateurs Quatitatifs (Eponges, Bivalves et Gastéropodes). Ph.D. Thesis, Université Paris 7 Denis Diderot, France.

Roy S, Gaillardet J, Allègre CJ (1999) Geochemistry of dissolved and suspended loads of the Seine river, France: Anthropogenic impact, carbonate and silicate weathering. Geochim Cosmochim Acta 63:1277-1292. doi:10.1016/S0016-7037(99)00099-X

Saad Z, Kazpard V, El Samrani AG, Slim K (2005a) Chemical and isotopic composition of rainwater in coastal and highland regions in Lebanon. J Environ Hydrol 13:1-11.

Saad Z, Kazpard V, Slim K, Mroueh M (2005b) A Hydrochemical and Isotopic Study of Submarine Fresh Water Along the Coast in Lebanon. J Environ Hydrol 13:1-16.

Sene KJ, Marsh TJ, Hachache A (1999) An assessment of the difficulties in quantifying the surface water resources of Lebanon. Hydrol Sci J 44. doi:10.1080/02626669909492204

Shaban A, Darwich T, Assaker A, Poupet P, Harfouche R (2015) Evaluation des Caractéristiques Physiques et des Risques Naturels dans le Bassin Versant du Nahr Ibrahim, in: Harfouche, R., Poupet, P. (Eds.), Du Mont Liban Aux Sierras d'Espagne. Sols, Eau et Sociétés En Montagne. Archaeopress Publishing Ltd., Oxford, England, pp. $39-50$.

Shaban A, Darwich T, Drapeau L, Gascoin S (2014) Climatic Induced Snowpack Surfaces on Lebanon's Mountains. Open Hydrol J 8:8-16.

Singurindy O, Berkowitz B (2003) Flow, dissolution, and precipitation in dolomite. Water 
Resour Res 39:1143. doi:10.1029/2002WR001624

Stallard RF, Edmond JM (1981) Geochemistry of the Amazon: 1. Precipitation chemistry and the marine contribution to the dissolved load at the time of peak discharge. J Geophys Res 86:9844-9855.

Sun H, Han J, Li D, Zhang S, Lu X (2010) Chemical weathering inferred from riverine water chemistry in the lower Xijiang basin, South China. Sci Total Environ 408:4749-4760. doi:10.1016/j.scitotenv.2010.06.007

Szramek K, Walter LM (2004) Impact of carbonate precipitation on riverine inorganic carbon mass transport from a mid-continent, forested watershed. Aquat Geochemistry 10:99137.

Szramek K, Walter LM, Kanduč T, Ogrinc N (2011) Dolomite Versus Calcite Weathering in Hydrogeochemically Diverse Watersheds Established on Bedded Carbonates (Sava and Soča Rivers, Slovenia). Aquat Geochemistry 17:357-396. doi:10.1007/s10498-0119125-4

Whipkey CE, Capo RC, Chadwick OA, Stewart BW (2000) The importance of sea spray to the cation budget of a coastal Hawaiian soil: A strontium isotope approach. Chem Geol 168:37-48. doi:10.1016/S0009-2541(00)00187-X

Williams EL, Szramek KJ, Jin L, Ku TCW, Walter LM (2007) The carbonate system geochemistry of shallow groundwater-surface water systems in temperate glaciated watersheds (Michigan, USA): Significance of open-system dolomite weathering. Bull Geol Soc Am 119:515-528. doi:10.1130/B25967.1

Zavadlav S, Kanduč T, McIntosh J, Lojen S (2013) Isotopic and Chemical Constraints on the Biogeochemistry of Dissolved Inorganic Carbon and Chemical Weathering in the Karst Watershed of Krka River (Slovenia). Aquat Geochemistry 19:209-230. doi:10.1007/s10498-013-9188-5

Zhu B, Yu J, Qin X, Rioual P, Xiong H (2012) Climatic and geological factors contributing to the natural water chemistry in an arid environment from watersheds in northern Xinjiang,China.Geomorphology153-154:102-114.

doi:10.1016/j.geomorph.2012.02.014 


\section{Figures and tables}

Figure 1: Geographic and geological setting of the Nahr Ibrahim watershed. The bold blue line represents the Nahr Ibrahim River. The yellow diamonds indicate the location of sampling sites. The Red triangle represents the Akoura meteorological station. The river profile is given below the geological map.

Figure 2: (a) Precipitation at Akoura Meteorological station. (b) Nahr Ibrahim discharge at Afqa gauging station and at Outlet. (c) Snow cover area in the Nahr Ibrahim watershed.

Figure 3: (a) $\mathrm{pH}$ and (b) electrical conductivity measurements at different sampling sites. Afqa; $\square$ Roueiss; $\square$ Yenouh; $\bigcirc$ Mzarib; $\triangle$ Janneh; $*$ Yahshoush; $\diamond$ Outlet. Samples collected during the wet season in blue, during the dry season in red.

Figure 4: Piper trilinear diagram for the Nahr Ibrahim water samples. Wet season samples are in blue, dry season samples are in red. ( $\dot{*}$ corresponds to $*$ in the other graphs, and + corresponds to $\diamond$ )

Figure 5: Plot of $\delta^{18} \mathrm{O}$ vs. $\delta \mathrm{D}$ for the Nahr Ibrahim water samples. Samples taken during the wet season are in blue, whereas samples taken during dry season are in red. The solid line shows the Lebanese Meteoric Water Line $\left(\delta \mathrm{D}=7.135 * \delta^{18} \mathrm{O}+15.979\right)$.

Figure 6: (a) Plot of $\mathrm{Ca}^{2+}+\mathrm{Mg}^{2+}$ versus $\mathrm{HCO}_{3}$ - for the Nahr Ibrahim watershed. The solid line shows the $\left(\mathrm{Ca}^{2+}+\mathrm{Mg}^{2+}\right): 2 \mathrm{HCO}_{3}^{-}$relationship. (b) $\mathrm{Mg}^{2+}$ versus $\mathrm{Ca}^{2+}$ for the Nahr Ibrahim watershed. The solid lines shows various $\mathrm{Mg}^{2+} / \mathrm{Ca}^{2+}$ ratios that characterize dolomite and/or calcite dissolution. (c) $\mathrm{Mg}^{2+}$ versus $\mathrm{HCO}_{3}{ }^{-}$. Afqa; $\square$ Roueiss; $\square$ Yenouh; $\bigcirc$ Mzarib; $\triangle$ Janneh; * Yahshoush; $\diamond$ Outlet. Wet season samples are in blue, dry season samples are in red.

Figure 7: (a) Plot of $\mathrm{Na}^{+}$versus $\mathrm{Cl}^{-}$. The solid line shows the $\mathrm{Na}^{+} / \mathrm{Cl}^{-}$ratio in local precipitations (Saad et al., 2000). (b) Plot of $\mathrm{SO}^{2-}$ versus $\mathrm{Cl}^{-}$. (c) Plot of $\mathrm{K}^{+}$versus $\mathrm{Cl}^{-}$. (d) Plot of $\mathrm{K}^{+}$versus $\mathrm{SO}_{4}{ }^{2-}$. $\bigcirc$ Afqa; $\square$ Roueiss; $\square$ Yenouh; $\bigcirc$ Mzarib; $\triangle$ Janneh; * Yahshoush; $\diamond$ Outlet. Samples collected during the wet season samples are in blue, samples collected during the dry season are in red.

Figure 8: Downstream evolution of (a) $\mathrm{Ca}^{2+}$; (b) $\mathrm{Mg}^{2+}$; (c) $\mathrm{HCO}_{3}{ }^{-}$(d) $\mathrm{Na}^{+}$; (e) $\mathrm{SO}_{4}{ }^{2-}$ and (f) $\mathrm{K}^{+}$. The distance is from the outlet of the Nahr Ibrahim River in the Mediterranean sea. Afqa; $\square$ Roueiss; $\square$ Yenouh; $\bigcirc$ Mzarib; $\triangle$ Janneh; $*$ Yahshoush; $\diamond$ Outlet. Wet season samples are in blue, dry season samples are in red.

Figure 9: Plot of $\delta \mathrm{D}$ versus $\mathrm{Cl}^{-}$for the Nahr Ibrahim water samples. The inset gives the variation of $\delta \mathrm{D}$ with the altitude of the sampling site. Wet season samples are in blue, dry season samples are in red.

Figure 10: Downstream evolution for the Nahr Ibrahim water samples of (a) calcite saturation index $\mathrm{SI}_{\text {Calcite }}$ and (b) dolomite saturation index $\mathrm{SI}_{\text {Dolomite. }} \odot$ Afqa; $\boldsymbol{\square}$ Roueiss; $\square$ Yenouh; $\bigcirc$ Mzarib; $\triangle$ Janneh; $*$ Yahshoush; $\diamond$ Outlet. Wet season samples are in blue, dry season samples are in red. 
Table 1: Summary of the different lithologies outcropping in the Nahr Ibrahim watershed.

\begin{tabular}{|c|c|c|c|}
\hline Symbol & Stage & Lithology & $\%$ of Basin area \\
\hline J6 & $\begin{array}{l}\text { Potlandian, Upper } \\
\text { Jurassic }\end{array}$ & $\begin{array}{l}\text { Karstified massive to medium bedded limestones with horizons of } \\
\text { dolomitic limestones, with thin marly limestone and chert nodules }\end{array}$ & 19.07 \\
\hline BJ6 & $\begin{array}{l}\text { Kimmeridgian, } \\
\text { Upper Jurassic }\end{array}$ & Upper Jurassic volcanism, basalts & 3.42 \\
\hline C1 & & $\begin{array}{l}\text { Cross-bedded or thin to thick bedded and massive sandstone with } \\
\text { intercalation of limestones, clays shales, highly jointed }\end{array}$ & 2.85 \\
\hline $\mathbf{C 2 a}$ & $\begin{array}{l}\text { Lower Aptian; } \\
\text { Lower Cretaceous }\end{array}$ & Clastic limestone, thin to thick bedded and jointed & 3.41 \\
\hline $\mathbf{C} 2 \mathrm{~b}$ & $\begin{array}{l}\text { Upper Aptian; } \\
\text { Lower Cretaceous }\end{array}$ & $\begin{array}{l}\text { Stylotics, partly dolomitic, medium to thick bedded and massive, } \\
\text { partly jointed and karstified }\end{array}$ & 2.91 \\
\hline$\beta C 2$ & & Basalts, agglomerates and tuffs, jointed, flow or bedded type & 1.62 \\
\hline $\mathbf{C 3}$ & $\begin{array}{l}\text { Albian; Lower } \\
\text { Cretaceous }\end{array}$ & $\begin{array}{l}\text { Calcareous shales interbedded with highly fossiliferous and clastic } \\
\text { limestone, thin to medium bedded and jointed }\end{array}$ & 2.04 \\
\hline $\mathrm{C4}$ & $\begin{array}{l}\text { Cenomanian; Upper } \\
\text { Cretaceous }\end{array}$ & $\begin{array}{l}\text { Well bedded limestone with few calcareous shale intercalations, } \\
\text { bedded and jointed }\end{array}$ & 60.12 \\
\hline qat & Quaternary deposits & Modern alluviums, alluvium terraces, landslides & 4.56 \\
\hline
\end{tabular}


Table 2: Main characteristics of sampling sites

\begin{tabular}{|c|c|c|c|c|c|c|}
\hline Site & Type & Latitude & Longitude & Altitude (m) & Distance to outlet (m) & $\begin{array}{c}\text { Geological } \\
\text { layer }\end{array}$ \\
\hline Afqa & Spring & 34 4'3.38"N & 35 53'34.97"E & 1147 & 29349 & qat \\
\hline Roueiss & Spring & 34 6'31.78"N & 35 54'30.49"E & 1201 & 30371 & qat \\
\hline Yenouh & Surface water & 34 5'36.6"N & 35 53'3.7"Е & 959 & 27346 & $\mathrm{C} 1$ \\
\hline Mzarib & Surface water & 34 4'28.6"N & 35 52'57.2'E & 993 & 28084 & $\mathrm{C} 1$ \\
\hline Janneh & Surface water & $344^{\prime} 45.8 " \mathrm{~N}$ & 35 49'39.9"E & 731 & 20784 & qat \\
\hline Yahsoush & Surface water & 34 4'38.94"N & 35 43'27.08"E & 256 & 9783 & J6 \\
\hline Outlet & Surface water & $343^{\prime} 36.73^{\prime \prime} \mathrm{N}$ & 35 38'55.8"E & 13 & 715 & qat \\
\hline
\end{tabular}


Table 3: Physico-chemical data for the Nahr Ibrahim watershed during the study period

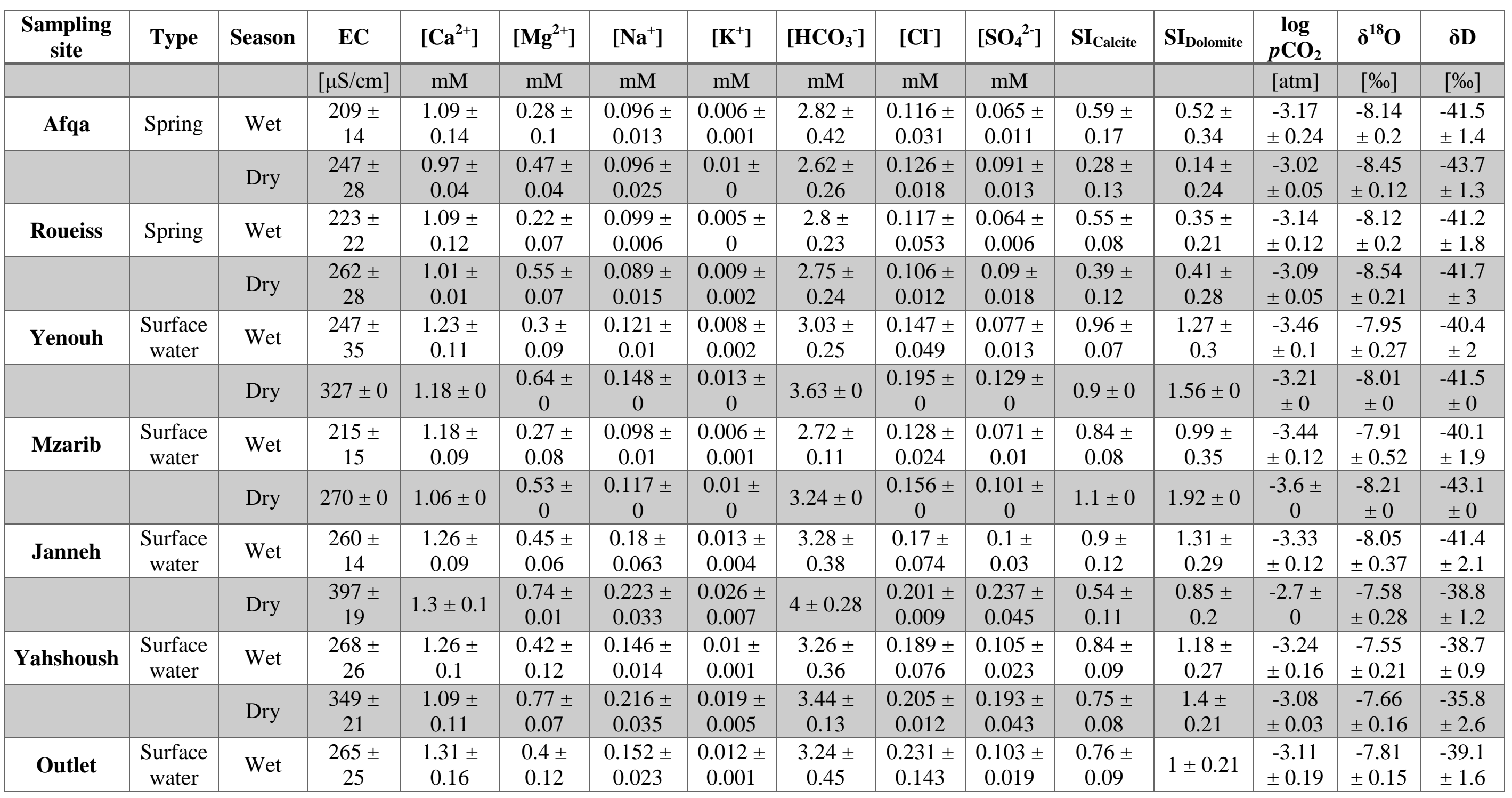




\begin{tabular}{|c|c|c|c|c|c|c|c|c|c|c|c|c|c|c|c|}
\hline & & Dry & $\begin{array}{c}346 \pm \\
60\end{array}$ & $\begin{array}{c}1.1 \pm \\
0.31\end{array}$ & $\begin{array}{c}0.8 \pm \\
0.06\end{array}$ & $\begin{array}{c}0.233 \pm \\
0.034\end{array}$ & $\begin{array}{c}0.028 \pm \\
0.014\end{array}$ & $\begin{array}{c}3.44 \pm \\
0.4\end{array}$ & $\begin{array}{c}0.207 \pm \\
0.049\end{array}$ & $\begin{array}{c}0.146 \pm \\
0.035\end{array}$ & $0.3 \pm 0.3$ & $\begin{array}{c}0.56 \pm \\
0.77\end{array}$ & $\begin{array}{c}-2.56 \\
\pm 0.42\end{array}$ & $\begin{array}{c}-7.24 \\
\pm 0.04\end{array}$ & $\begin{array}{l}-34.8 \\
\pm 1.4\end{array}$ \\
\hline
\end{tabular}

